\title{
PEMBELAJARAN GEOGRAFI DARI MEDIA TUNGGAL MENUJU MULTIMEDIA
}

\author{
Silivester Kiik \\ Email: kiiksilivester@gmail.com
}

\begin{abstract}
Abstrak: Refleksi pembelajaran geografi dalam satu dasa warsa terakhir menunjukkan kemerosotan pada pengetahuan, sikap, dan keterampilan siswa akibat media tunggal sebagai peran penting dalam proses pembelajaran. Kemerosotan tersebut menguatkan pentingnya pembelajaran dengan menerapkan multimedia sebagai media pembelajaran. Hasil kajian terhadap pembelajaran multimedia menunjukkan: pertama, mampu meningkatkan motivasi dan hasil belajar siswa. Kedua, mampu meningkatkan daya ingat siswa terhadap isi/materi pelajaran. Ketiga, mampu meningkatkan keaktifan berpikir siswa. Apabila pembelajaran multimedia dapat dikembangkan dengan baik, maka tujuan pembelajaran diharapkan dapat tercapai secara efektif dan efisien.
\end{abstract}

Kata kunci: pembelajaran geografi, media tunggal, multimedia

\section{PENDAHULUAN}

Penguatan pembelajaran multimedia semakin disadari sejak beberapa tahun terakhir oleh guru sebagai pengelola kelas dalam membantu siswa belajar daripada guru mengajar (Hamalik, 2008; Ningrum dkk, 2013). Kesadaran itu tumbuh karena keprihatinan terhadap kemerosotan motivasi dan hasil belajar geografi yang terjadi di jenjang sekolah menengah, terutama siswa dalam proses pembelajaran terkesan membosankan dan jenuh serta materi pembelajaran tidak dicermati dengan baik oleh siswa. Hal tersebut dirasakan sangat merosot pengetahuan dan pengalaman belajarnya serta akan berdampak bagi masa depan siswa itu sendiri.

Keberadaan multimedia dalam pembelajaran menjadi penting sebab dengan adanya multimedia maka materi pembelajaran geografi dapat tersampaikan lebih konkret. Penggunaan multimedia dapat meningkatkan efektifitas dari penyampaian suatu informasi (Arifin, 2012; Hasrul 2010). Multimedia yang baik adalah multimedia yang mampu menghadirkan dan membangkitkan dimensi-dimensi kognitif, afektif dan psikomotor siswa, sehingga melalui media tersebut akan diperoleh pengalaman belajar yang berkesan oleh siswa.

Kehadiran media dalam proses pembelajaran mempunyai fungsi yang cukup penting, karena dalam kegiatan tersebut ketidakjelasan bahan yang disampaikan guru dapat dibantu dengan menghadirkan media sebagai perantara. Kerumitan bahan yang akan disampaikan kepada siswa dapat disederhanakan dengan bantuan media. Menurut Amrulloh, dkk (2013) media pembelajaran berfungsi untuk mempermudah siswa dalam memahami suatu materi. Penggunaan media dalam proses pembelajaran yang berpusat pada siswa akan berdampak positif bagi prestasi belajarnya. Pekerjaan guru adalah mengkomunikasikan pengalaman kepada siswa, dan guru berperan sebagai fasilitator, mediator, dan evaluator.

Kegiatan proses pembelajaran geografi yang terjadi selama ini sebagian besar guru hanya menyajikan informasi dalam bentuk verbal sehingga kurang efektif bagi siswa, hanya mengandalkan papan tulis sebagai media utama, hanya memfasilitasi siswa yang memiliki cara belajar audio, sedangkan siswa dengan tipe belajar yang lain tidak maksimal. Ibrahim (2010) mengemukakan bahwa ketersediaan media pembelajaran akan memperluas kesempatan belajar tidak hanya terbatas pada siswa dengan tipe belajar verbal tapi juga siswa-siswa dengan tipe belajar yang lain seperti 
kinestetik, audio, musikal dan lain sebagainya. Sedangkan menurut Susilana (2007) manfaat media pembelajaran dapat memperjelas pesan agar tidak terlalu verbalistis.

Media yang digunakan haruslah tepat dan efektif agar siswa dapat dengan mudah menangkap pesan dan kesan pembelajaran serta menguasai kompetensi yang diharapkan. Media pembelajaran yang baik adalah media yang dapat dipersepsi dengan baik oleh siswa. Persepsi dimaknai sebagai proses kognitif yang dialami seseorang dalam memahami pesan/informasi dari lingkungan melalui indera penglihatan, pendengaran, perabaan, perasaan, maupun penciuman. Persepsi seseorang dipengaruhi oleh tingkat kebutuhannya terhadap sesuatu, artinya seseorang akan memberikan reaksi positif apabila hal itu merupakan kebutuhan baginya. Agar pembelajaran geografi menarik minat dan perhatian siswa, guru harus menyediakan media yang memadai berupa multimedia.

\section{Pembelajaran Geografi dengan Media Tunggal}

Media tunggal merupakan alat yang dapat digunakan dalam menyampaikan materi pembelajaran. Media tunggal sebagai sarana untuk memberikan pesan dari guru kepada siswa tanpa adanya umpan balik. Papan tulis digunakan sebagai media yang dianggap dapat memberikan semua pesan guru. Pesan disampaikan secara monoton oleh guru kepada siswa, dan siswa tidak dapat atau tidak mempunyai kesempatan untuk memberikan umpan balik atau bertanya. Guru juga menerapkan sistem komunikasi satu arah yang bisa dikatakan sebagai komunikasi yang tidak memberi kesempatan kepada siswa untuk memberikan tanggapan atau sanggahan.

Kegiatan proses pembelajaran yang dilaksanakan setiap hari merupakan kehidupan dari sebuah kelas, di mana guru dan siswa saling terkait dalam pelaksanaan kegiatan yang telah direncanakan oleh guru. Keberhasilan kegiatan tersebut sepenuhnya menjadi tanggung jawab guru, karena guru merupakan pengelola tunggal di dalam kelas. Dalam proses pembelajaran harus terjadinya interaksi antara guru dan siswa yaitu proses penyampaian pesan berupa informasi atau keterangan dari pengirim (sumber pesan/guru) kepada penerima pesan (siswa).

Keberhasilan pembelajaran di kelas ditentukan oleh berbagai faktor diantaranya, bagaimana strategi penyampaian materi dapat dilaksanakan secara efektif dan efesien dalam mencapai tujuan pembelajaran. Guru yang baik senantiasa mencari berbagai kemungkinan dalam strategi penyampaian materi pembelajaran. Hal ini dimaksudkan agar guru tidak terjebak dalam rutinitas mengajar yang membosankan, dan akan mengakibatkan suatu kondisi kelainan psikis guru yang negatif yang tidak diharapkan seperti mudah marah, egois dan lain-lain (Barlow, 1985). Jika demikian adanya maka jangan harap pendidikan akan berlangsung dengan baik.

Kelebihan media tunggal adalah sebagai berikut: 1) tidak memerlukan banyak pekerjaan dan persiapan, 2) penyajian pelajaran dapat dilakukan dengan jelas oleh guru selangkah demi selangkah dan secara sistematis, 3) dapat menjelaskan hal-hal sesaat (misalnya untuk menjawab pertanyaan), 4) apabila terdapat kekeliruan atau kesalahan dapat dilihat dan segera diperbaiki oleh guru secara langsung, 5) merangsang siswa untuk dapat belajar secara efektif, 6) siswa dapat melihat dan dapat membaca dengan jelas apa yang ditulis oleh guru di papan tulis, dan 7) memotivasi siswa untuk terbiasa bekerja pada papan tulis.

Sedangkan kekurangan dari media tunggal adalah sebagai berikut: 1) guru merasa tidak tenang apabila menggunakan papan tulis, merasa tidak mempunyai kecakapan menulis, dan menyebabkan keragu-raguan serta timbul rasa segan untuk menggunakan papan tulis sebagai media pembelajaran, 2) materi pembelajaran tidak dicermati dengan baik oleh siswa, 3) siswa merasa bosan dan jenuh, 4) tidak 
membangun pengetahuan siswa, 5) konsentrasi siswa hanya berfokus pada bunyi bel sekolah untuk pulang.

Pembelajaran geografi dengan menerapkan media tunggal lebih difokuskan pada guru. Guru memiliki kebiasaan masuk ke kelas meminta siswa membuka buku pada halaman tujuan untuk memulai proses pembelajaran, kemudian melanjutkannya dengan penjelasan/ceramah yang diselingin dengan tanya jawab. Kesimpulan hasil belajar juga disampaikan secara lisan. Guru ke luar kelas dalam keyakinan penuh bahwa siswa yang dibimbingnya telah menyerap dengan baik proses pembelajaran yang dibimbingnya.

Guru yang demikian melupakan konsep multiple intelligence dan cara belajar yang berbeda dan khas pada setiap individu. Tidak semua siswa memiliki dominasi cara belajar yang bersifat audio. Siswa yang memiliki kemampuan audio yang dominan tentu akan puas dan baik kompetensinya dengan cara tersebut, namun siswa yang cenderung ke pembelajaran visual dan kinestetik tidak akan memperoleh kompetensi yang memadai melalui proses pembelajaran yang dibimbing oleh guru tersebut.

Pembelajaran geografi harus mengarahkan siswa untuk berpikir kreatif sesuai dengan kenyataan yang terjadi. Siswa aktif belajar dibantu oleh media yang didesain oleh guru, di mana media tersebut dapat memberikan ide-ide yang kontekstual terhadap isi materi pelajaran. Sudah menjadi keharusan dengan tersedianya media dalam proses pembelajaran geografi. Guru sebagai fasilitator bertugas untuk mempelajari bagaimana menetapkan dan menggunakan media pembelajaran agar dapat mengefektifkan pencapaian tujuan pembelajaran dalam proses pembelajaran. Secara otomatis penggunaan media yang baik akan memberi manfaat yang banyak bagi siswa.

\section{Pembelajaran Geografi dengan Multimedia}

Seorang guru dalam melaksanakan proses pembelajaran harus memiliki gagasan yang ditunjukkan dalam desain pembelajaran, sebagai titik awal dalam melaksanakan komunikasi dengan siswa. Oleh karena itu, diperlukan pemahaman tentang unsur-unsur yang dapat menunjang proses komunikasi serta tujuan dari komunikasi tersebut. Agar proses komunikasi proses pembelajaran berjalan secara efektif dan efisien, guru perlu menggunakan media untuk merangsang siswa dalam belajar. Jadi, pada prinsipnya media bermanfaat untuk menunjang proses pembelajaran, hal ini bukan saja membuat penyajian menjadi lebih konkret, tetapi juga ada beberapa kegunaan yang lain.

Multimedia merupakan alat yang dapat menciptakan presentasi yang dinamis dan interaktif yang mengkombinasikan teks grafik, animasi, audio dan video. Istilah multimedia berkenaan dengan penggunaan berbagai jenis/bentuk media secara berurutan maupun simultan dalam menyajikan suatu informasi. Secara etimologis multimedia berasal dari bahasa Latin yang terdiri atas dua kata yaitu multi yang berarti banyak atau bermacam-macam dan medium yang diartikan sebagai perantara atau pengantar terjadinya komunikasi dari pengirim menuju ke penerima (Heinich dkk, 1996).

Konsep multimedia didefinisikan oleh Haffost (dalam Munir, 2008) sebagai suatu sistem komputer yang terdiri dari hardware dan software yang memberikan kemudahan untuk menggabungkan gambar, video, fotografi, grafik, animasi, suara, teks, dan data yang dikendalikan oleh komputer. Sejalan dengan hal tersebut, Robin dan Linda (2001) mengemukakan bahwa multimedia merupakan alat yang dapat menciptakan presentasi yang dinamis dan interaktif yang mengkombinasikan teks grafik, animasi, audio dan video. Oleh karena itu multimedia merupakan salah satu sumber pengajaran atau media alternatif dalam pembelajaran geografi yang dapat 
memadukan dan mengaitkan unsur lingkungan fisik dan manusia dalam dimensi keruangan.

Multimedia merupakan kombinasi dari berbagai jenis media seperti teks, grafik, suara, animasi dan video dalam aplikasi komputer (Merril dkk, 1996). Pengertian yang sama diungkapkan oleh Hackbarth (1996) yaitu:

Multimedia is suggested as meaning the use of multiple media formats for the presentation of information, including texts, still or animated graphics, movie segments, video, and audio information. Computer-based interactive multimedia includes hypermedia and hypertext. Hypermedia is a computer-based system that allows interactive linking of multimedia format information including text, still or animated graphic, movie segments, video, and audio. Hypertext is a non-linier organized and accessed screens of text and static diagrams, pictures, and tables.

Lebih lanjut Hofstetter yang dikutip Suyanto (2005) menyatakan ada empat komponen penting multimedia yaitu: (1) harus ada komputer yang mengkoordinasikan apa yang dilihat dan didengar, dan berinteraksi dengan pengguna, (2) harus ada link yang menghubungkan kita dengan informasi, (3) harus ada alat navigasi yang memandu pengguna menjelajah jaringan informasi, (4) multimedia menyediakan tempat kepada pengguna untuk mengumpulkan, memproses, mengomunikasikan informasi dan ide.

Pembelajaran dengan suasana kebebasan (permissive) memberikan seluasluasnya kepada siswa untuk melakukan eksplorasi dan mengembangkan kemampuan diri. Sementara kewajiban guru harus dapat menumbuhkan daya cipta melalui sesuatu yang dengan sadar dan dirancang untuk pencapaian tujuan pembelajaran (learning resources by design). Pembelajaran menggunakan media termasuk pengajaran direncanakan secara intensional. Media pembelajaran adalah segala sesuatu yang digunakan untuk menyalurkan pesan yang dapat merangsang pikiran, perasaan, perhatian, dan kemauan siswa sehingga dapat mendorong siswa untuk belajar.

Johan Amos Comenius, dengan teori "Dikdaktik Realisme" (Sudjana, 1989) menyatakan: 1) pengajaran yang diutamakan adalah adalah pengajaran yang bersifat kenyataan, bukan hanya kata-kata hampa yang bersifat verbalistik, 2) pengajaran yang baik melalui media, yaitu pendayagunaan alat-alat penginderaaan, 3) pelajaran disampaikan secara induktif, dimulai dari peristiwa nyata, meningkat ke umum, kesimpulan atau dalil yang abstrak, 5) pengajaran harus maju teratur dari pelajaran yang mudah menuju yang sukar.

Pembelajaran berbantuan multimedia dalam proses pembelajaran geografi dapat diartikan sebagai aplikasi multimedia yang digunakan dalam menyalurkan pesan (pengetahuan, keterampilan dan sikap) serta dapat merangsang pikiran, perasaan, perhatian, dan kemauan belajar sehingga terjadi proses belajar yang sesuai tujuan dan terkendali (Istiyanto, 2011). Menurut Mayer (2009), asumsi yang mendasari teori kognitif tentang multimedia learning, yakni dual-channel (saluran ganda), limited capacity (kapasitas terbatas), dan active-processing (pemrosesan aktif). Asumsi saluran ganda (dual channel assumption) menyatakan bahwa manusia memiliki saluran terpisah bagi pemrosesan informasi untuk materi visual dan materi auditori. Informasi berupa kata-kata diterima oleh mata dan telinga, sedangkan gambar diterima oleh mata yang merupakan memori sensorik. Setelah diseleksi oleh memori sensorik, informasi diteruskan ke memori kerja. Dalam memori kerja, informasi diorganisasikan untuk diintegrasikan yang selanjutnya diteruskan ke memori jangka panjang.

Menurut Sweller (2009), jika kapasitas kognitif siswa kelebihan beban (overload cognitive) maka pembelajaran akan terganggu. Sehingga untuk mengatasi 
kesulitan belajar siswa antara lain melalui pembelajaran yang efektif dengan mengelola beban kognitif intrinsic, mengurangi beban kognitif extraneous dan meningkatkan beban kognitif germane (Kalyuga, 2009). Mayer dan Moreno (2010) menegaskan bahwa untuk mewujudkan pembelajaran yang efektif dapat dibantu dengan multimedia, karena multimedia efektif untuk mengelola beban kognitif intrinsic, mengurangi beban kognitif extraneous dan meningkatkan beban kognitif germane.

Teori belajar kognitif menekankan skema pelajar terorganisir sebagai struktur pengetahuan (Bruner, 1990; Gagne dkk, 1993). Tidak seperti behaviorisme, kognitivisme mengakui bahwa pikiran manusia bukan hanya penerima pasif pengetahuan. Sebaliknya, siswa menafsirkan pengetahuan dan memberi makna untuk itu (Hadjerroit, 2008). Mereka menunjukkan bagaimana seorang siswa memandang, proses, menafsirkan dan mengambil informasi terutama berkaitan dengan perubahan dalam pemahaman siswa yang dihasilkan dari pembelajaran. Siswa terlibat dalam proses pembelajaran, sehingga guru harus menyajikan informasi yang terorganisir dalam cara berhubungan dengan siswa. Shuell (1986) menekankan bahwa pendekatan kognitif menekankan belajar sebagai sebuah konstruktif dan proses berorientasi tujuan aktif yang tergantung pada aktivitas mental dari siswa.

Teori belajar konstruktivis memandang pengetahuan sebagai entitas yang dibangun oleh setiap siswa melalui proses pembelajaran. Pembelajaran konstruktivis mengharuskan siswa untuk menunjukkan kemampuan mereka dengan membangun pengetahuan mereka sendiri ketika memecahkan masalah di dunia nyata. Model konstruktivis sebagai instruksi yang berpusat pada siswa, karena siswa diasumsikan untuk belajar lebih baik ketika mereka diajak untuk mengeksplorasi dan menemukan hal-hal yang baru.

Siswa dipimpin untuk aktif membangun ide-ide baru menggunakan pengetahuan sebelumnya dan pengalaman yang diperoleh. Selama proses pembelajaran, guru berperan sebagai fasilitator, mengoreksi, mendorong pemahaman baru, dan menciptakan sikap sosial antar siswa. Siswa pada gilirannya mengambil tanggung jawab belajar dengan aktif berpartisipasi dalam kegiatan pembelajaran dan ditempatkan sebagai pusat proses pembelajaran.

Dimensi proses pengetahuan terbagi dalam tiga yaitu kognitif, afektif dan psikomotor (Anderson \& Krathwohl, 2001) ranah kognitif terbagi dalam enam tingkat yaitu : 1) mengingat (remember): mengambil, mengakui, dan mengingat pengetahuan yang relevan dari memori jangka panjang, 2) memahami (understand): membangun makna dari lisan, pesan tertulis, dan grafis melalui menafsirkan, mencontohkan, mengklasifikasi, meringkas, menyimpulkan, membandingkan, dan menjelaskan, 3) menerapkan (apply): melaksanakan atau menggunakan prosedur melalui pelaksana, atau menerapkan, 4) menganalisis (analyze): breaking materi menjadi bagian-bagian penyusunnya, menentukan bagaimana bagian-bagian berhubungan satu sama lain dan yang secara keseluruhan struktur atau tujuan melalui membedakan, mengorganisasikan, dan menghubungkan, 5) evaluasi (evaluate): membuat penilaian berdasarkan kriteria dan standar melalui memeriksa dan mengkritisi, dan 6) menciptakan (create): menempatkan elemen bersama-sama untuk membentuk suatu kesatuan yang utuh atau fungsional, reorganisasi elemen ke pola baru atau struktur melalui menghasilkan, perencanaan, atau menghasilkan.

Multimedia memiliki kelebihan dalam proses pembelajaran sebagai berikut: 1) meningkatkan aliran gagasan dan informasi, 2) merupakan cara yang kaya untuk mengkomunikasikan sesuatu, 3) mendorong partisipasi, keterlibatan, dan eksplorasi pengguna, 4) menstimulasi panca indera, 5) meningkatkan pengetahuan, 6) membawa dunia nyata di dalam kelas, 7) siswa semangat dan aktif dalam proses pembelajaran. 
Sedangkan kekurangan multimedia adalah sebagai berikut: 1) desain yang buruk akan menyebabkan kebingungan dan kebosanan atau pesan yang tidak tersampaikan dengan baik, 2) kendala bagi orang yang memiliki keterbatasan seperti cacat fisik, 3) tuntunan terhadap spesifikasi komputer yang memadai.

Penggunaan multimedia yang interaktif tidak terlepas dari penggunaan komputer sebagai media karena multimedia interaktif hanya dapat di jalankan melalui komputer atau teknologi berbasis komputer, sehingga selain pengadaan komputer dan program sebagai media juga dibutuhkan keterampilan dalam mengoperasikan komputer. Dalam penggunaan multimedia sangat bergantung pada jenis materi/content yang akan diberikan terutama dalam materi-materi pelajaran geografi.

\section{Pergeseran Pembelajaran Geografi dari Media Tunggal Menuju Multimedia}

Karakteristik materi geografi adalah berupa fakta, konsep, prinsip, dan proses dari gejala-gejala hidup, serta seluk beluk yang mempengaruhi hidup termasuk interaksinya dengan lingkungan. Materi geografi terus mengalami perkembangan sejalan dengan penemuan-penemuan baru dalam bidang geografi dan cabangcabangnya, serta perkembangan ilmu pengetahuan dan teknologi. Materi geografi dapat dipandang sebagai suatu yang sederhana, namun dapat juga dipandang sebagai sesuatu yang sangat rumit dan kompleks. Mengajarkan geografi yang rumit dan kompeks memerlukan media dalam pembelajarannya.

Dewasa ini terjadinya perkembangan geografi dan dan teknologi geografi yang semakin pesat. Keadaan ini mendorong para guru geografi untuk melakukan pembaharuan dalam pemanfaatan hasil-hasil teknologi dalam proses pembelajaran geografi. Banyak cara yang dapat dilakukan dalam pemanfaatan teknologi komunikasi. Dari sekian banyak produk teknologi komunikasi yang dapat dimanfaatkan dalam dunia pendidikan dan pembelajaran geografi adalah dalam penggunaan multimedia. Dengan demikian, dalam proses pembelajaran geografi, guru tidak hanya menggunakan media tunggal, tetapi sebaiknya menggunakan multimedia. Ngalim (1992) menyatakan bahwa proses pembelajaran pada hakikatnya adalah proses komunikasi, yaitu proses penyampaian pesan dari sumber pesan melalui saluran atau media tertentu ke penerima pesan.

Agar mempermudah siswa dalam menerima materi pelajaran geografi perlu dibantu dengan media pembelajaran. Gejala dan fakta yang terdapat dalam alam dan lingkungan sekitarnya akan lebih menarik disampaikan guru kepada siswa bila dengan menggunakan media. Pentingnya media pembelajaran digunakan agar siswa menjadi lebih tertarik dalam proses pembelajaran. Masalahnya, adalah bagaimana guru geografi dapat melakukan inovasi terutama dalam menggunakan media dalam setiap pembelajaran geografi. Ini memerlukan kreativitas guru geografi dalam memproduksi dan memanfaatkan media dalam setiap berlangsungnya pembelajaran.

Keluhan guru geografi terutama yang mengajar pada sekolah yang minim fasilitasnya adalah sulitnya memberikan pemahaman materi kepada siswa dengan menggunakan media. Kebanyakan guru mengajar tanpa menggunakan media, karena media tidak cukup tersedia untuk semua materi pelajaran. Jadi, pembelajaran geografi berlangsung dengan ceramah tanpa menggunakan media, sehingga siswa mengalami kesulitan dalam memahami isi materi pelajaran. Mereka hanya dapat menghayalkan saja apa yang dikatakan oleh guru. Paling tidak guru hanya menggunakan gambar yang dibuatnya di papan tulis. Keadaan seperti ini bila dipertahankan terus dapat memberikan kesan bahwa materi geografi itu sulit dipahami. 
Guru geografi memiliki peran yang sangat penting dalam pemanfaatan media. Kreativitas sangat dituntut bagi guru geografi agar mereka dapat menciptakan media pembelajaran geografi yang menarik. Apalagi, sekarang ini guru geografi tidak hanya dapat menghandalkan media tunggal dalam proses pembelajaran. Setidak-tidaknya guru geografi dapat memanfaatkan berbagai bentuk media pembelajaran untuk mempermudah penyampaian isi materi pelajaran.

Guru memiliki peran yang sangat penting dalam proses pembelajaran. Siswa dikatakan belajar memerlukan media agar mereka mudah memahami materi pelajaran. Alat indera seperti penglihatan dan pendengaran merupakan bagian yang terpenting untuk belajar. Apabila mekanisme mata atau telinga kurang berfungsi, maka tanggapan yang disampaikan dari dunia luar umpamanya dari guru, tidak mungkin dapat diterima oleh orang yang bersangkutan. Oleh sebab itu, siswa tidak dapat menerima dan memahami bahan-bahan pelajaran dengan baik dan sempurna bila alat indera seperti mata dan telinga ini terganggu (Majid, 2007). Untuk melihat sejauh mana tujuan pengajaran telah dapat dicapai atau materi pelajaran telah dikuasai oleh siswa maka dapat diketahui dalam bentuk hasil belajar yang diperlihatkan setelah mereka menempuh proses pembelajaran.

Mengajar dapat dipandang sebagai usaha yang dilakukan guru agar siswa belajar. Belajar pada dasarnya adalah upaya untuk memperoleh pengalaman dalam perubahan tingkah laku. Untuk mempermudah memperoleh pengalaman langung ini, seseorang yang belajar membutuhkan perantara dalam memahami materi pelajaran. Di sinilah pentingnya media pembelajaran (Hasruddin, 2009). Menurut Hamalik (2008) bahwa pemakaian media pembelajaran dapat membangkitkan keinginan dan minat yang baru, membangkitkan motivasi, rangsangan kegiatan belajar, dan bahkan membawa pengaruh psikologis terhadap siswa.

Kehadiran media mempunyai arti yang cukup penting karena kerumitan bahan yang akan disampaikan kepada siswa dapat disederhanakan dengan bantuan media. Media merupakan alat yang digunakan sebagai perantara untuk menyampaikan pesan dan dapat merangsang pikiran, perasaan dan kemajuan audiens (siswa) sehingga dapat mendorong terjadinya proses pembelajaran (Majid, 2007). Media sebagai alat bantu dalam proses belajar mengajar adalah sesuatu yang tidak dapat dipungkiri. Pada kenyataannya memberikan pengalaman langsung kepada siswa bukan sesuatu yang mudah bukan hanya menyangkut segi perencanaan dan waktu saja yang menjadi kendala, akan tetapi memang ada sejumlah pengalaman yang sangat tidak mungkin dipelajari secara langsung oleh siswa. Melihat pentingnya penggunaan media dalam pembelajaran, maka menurut Sanjaya (2008) bahwa fungsi dan peranan media dalam pembelajaran adalah: 1) menangkap suatu objek atau peristiwa-peristiwa tertentu, 2) memanipulasi keadaan, peristiwa, atau objek tertentu, dan 3) menambah gairah dan memotivasi belajar siswa. Dalam penggunaan media belajar pada prinsipnya adalah bagaimana siswa dapat dengan lebih mudah dalam belajar. Dengan adanya media siswa menjadi terangsang untuk lebih mencari tahu tentang materi yang diajarkan guru.

\section{KESIMPULAN}

Penggunaan multimedia dalam pembelajaran geografi saat sekarang ini sudah saatnya dilakukan. Guru geografi tidak wajar lagi dalam mengajar tanpa menggunakan media. Pembelajaran geografi akan menjadi lebih kontekstual, karena materi yang diajarkan sangat berkaitan langsung dengan kehidupan nyata siswa. Guru geografi harus kreatif dalam menciptakan dan menggunakan media pembelajaran. Dalam proses pendidikan modern sekarang ini penggunaan multimedia tidak menjadi asing lagi. Dengan penggunaan multimedia ini, diharapkan proses pembelajaran geografi akan 
semakin berkualitas dan pada akhirnya akan terjadi peningkatan kualitas sumber daya manusia secara keseluruhan.

Pembelajaran geografi di sekolah membutuhkan sentuhan baru dalam kemasan proses pembelajarannya agar pembelajaran geografi lebih menarik dan minat siswa dapat meningkat. Namun tidak mengesampingkan tujuan serta hasil yang ingin dicapai. Salah satu usaha yang dilakukan yaitu dengan penggunaan multimedia, di mana dalam prosesnya dapat melibatkan siswa dan media secara lansung dan interaktif. Pengalaman siswa akan lebih bertambah dan siswa tidak akan terpaku kepada materi yang ada, akan tetapi dapat memilih sesuai apa yang dibutuhkannya dan kemampuannya melalui kondisi yang berbeda dengan pembelajaran secara konvensional di dalam kelas.

Pembelajaran geografi dengan menggunakan multimedia dapat membangun nilai-nilai karakter siswa yang berpengetahuan, cerdas dan kreatif, tanggung jawab dan arif, peduli lingkungan, sosial dan budaya, berpikir terbuka dan toleran, pro aktif perubahan, dan berkomunikasi baik. Nilai-nilai tersebut sesuai dengan perkembangan zaman dan tugas pendidikan ke depan.

\section{DAFTAR RUJUKAN}

Amrulloh, R. Yuliani., Isnawati. 2013. Kelayakan Teoritis Media Pembelajaran Multimedia Interaktif Materi Mutasi untuk SMA (The Feasibility Theoretical of Learning Media of Interactive Multimedia in the Topic of Mutation for Senior High School). Jurnal BioEdu (Berkala Ilmiah Pendidikan Biologi). Vol. 2 No. 2 Mei 2013. ISSN: 2302-9528. Jurusan Biologi FMIPA UNESA.

Anderson, L.W., dan Krathwohl, D. R. 2001. A Taxonomy for Learning, Teaching, and Assesing: A Revision of Bloom's Taxonomy of Educatioanl Objectives. New York: Addison Wesley Longman, Inc.

Arifin, Zainal dan Adhi Setiyawan. 2012. Pengembangan Pembelajaran Aktif dengan ICT. Yogyakarta : PT Skripta Media Creative.

Barlow. 1985. Supervision and Teacher: A Private Coldwar. Berkeley; Mc Cutchan. N.Y.

Bruner, J. 1990. Acts of Meaning. Cambridge, MA: Harvard University Press.

Gagne, E., C. Yekovich, and F. Yekovisch. 1993. The Cognitive Psychology of School Learning. 2nded. New York: HarperCollins.

Hackbarth, S. 1996. The Educational Technology Hand-book A Comprehensive Guide Process and Products For Learning. New Jersey: Educati-onal Technology Publications

Hadjerrouit, S. 2008. Using a Learner-Centered Approach to Teach ICT in Secondary Schools: An Exploratory Study. Issues. Informing Science and Information Technology 5: 233-257.

Hamalik, O. 2008. Kurikulum dan Pembelajaran. Jakarta: Bumi Aksara.

Hamalik, O. 2008. Metodologi Pengajaran Ilmu Pendidikan. Bandung: Penerbit Mandar Maju. 
Hasruddin. 2009. Peran Multi Media dalam Pembelajaran Biologi. Jurnal Tabularasa PPS UNIMED Vol.6 No.2, Desember 2009.

Hasrul. 2010. Langkah-Langkah Pengembangan Pembelajaran Multimedia Interaktif. Jurnal MEDTEK II (2).

Heinich, R., et al. 1996. Instructional Media and Technology for Learning. New Jersey: Pretince Hall. Inc.

Ibrahim, Muslimin, dkk. 2010. Dasar-Dasar Proses Belajar Mengajar. Surabaya: Unesa University Press.

Istiyanto, 2011, Pengertian dan Manfaat Multimedia Pembelajaran. Diakses di http://istiyanto.com/pengertian-dan-manfaat-multimedia-pembelajaran/ Diakses tanggal 14 April 2016.

Kalyuga, S. 2009. Schema Acquisition and Sources of Cognitive Load. Dalam JL. Plass, R. Moreno, \& R. Brunken (Eds.). Cognitive Load Theory (hlm.48-64). New York: Cambridge University Press.

Majid, A. 2007. Perencanaan Pembelajaran. Bandung: PT Remaja Rosdakarya.

Mayer, R. E. 2009. Multimedia Learning: Prinsip-Prinsip dan Aplikasi. Terjemahan Teguh Wahyu Utomo. Yogyakarta: Pustaka Pelajar.

Mayer, RE \& Moreno, R. 2010. TechniquesThat Reduce Extraneous Cognitive Load and Manage Intrinsic Cognitive Load during Multimedia Learning. Dalam JL. Plass, R. Moreno, \& R. Brunken (Eds.). Cognitive Load Theory (hlm.131-149). New York: Cambridge University Press.

Merril, Paul F. et. al. 1996. Computers in Education. Boston: Allyn\&Bacon

Munir. 2008. Kurikulum Berbasis Teknologi Informasi dan Komunikasi. Bandung: Alfabeta.

Ngalim, M. 1992. Psikologi Pendidikan. Bandung: Remaja Rosdakarya.

Ningrum, dkk. 2013. Pengembangan Multimedia Pembelajaran Geografi Berbasis Pendidikan Karakter. Jurnal Geoedukasi Volume 2 Nomor 1, Maret 2013.

Robin, Linda. 2001. Menguasai Pembuatan animasi dengan Macromedia Flash. Jakarta: Elek Media Komputindo.

Susilana, R. 2007. Sumber Belajar dalam Pendidikan dalam Ilmu dan Aplikasi Pendidikan: Bagian II Pendidikan Disiplin Ilmu.Bandung: PT IMTIMA.

Sanjaya,W. 2008. Strategi Pembelajaran Berorientasi Standar Proses Pendidikan. Jakarta: Kenana.

Shuell, T. J. 1986. Cognitive Conceptions of Learning. Review of Educational Research 56.4: 411-436. 
Sudjana, N. \& Ibrahim. 1989. Penelitian dan Penilaian Pendidikan. Bandung: Sinar Baru.

Suyanto, M. 2005. Multimedia: untuk Meningkatkan Keunggulan Bersaing. Yogyakarta: Penerbit Andi offset.

Sweller, J. 2009. Cognitive Load Theory: Recent Theoretical Advances. Dalam JL. Plass, R. Moreno, \& R. Brunken (Eds.). Cognitive Load Theory (hlm.29-47). New York: Cambridge University Press. 